\title{
Research
}

\section{A Biodiversity Informatics Approach to Ethnobotany: Meta-analysis of Plant Use Patterns in Ecuador}

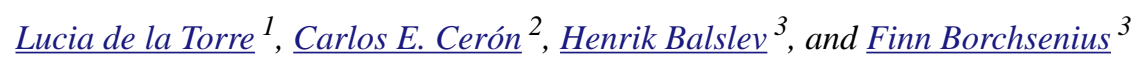

\begin{abstract}
We explored the relative importance of ecosystem diversity, socioeconomic, environmental, and geographical factors in determining the pattern and diversity of people's plant use in Ecuador, based on existing ethnobotanic investigations and a large database of georeferenced plant collections. For each of 40 communities, we determined the number of plants used and their distribution among 12 use categories. Plant species richness of the ecosystem surrounding each village was determined using herbarium data and rarefaction. Variation in socioeconomic, environmental, and geographical indicator variables at the community level was summarized using Principal Component Analysis (PCA). Data were then analyzed using multiple regression and ordination analysis. We found a significant positive relationship between the number of plant species used and ecosystem species richness, whereas socioconomic, environmental, and geographical factors had no significance. However, ordination analysis did show a clear link among these factors and plant use patterns, i.e., the relative importance of different use categories. Study communities were divided into two groups: 1) Andean and coastal communities with better access to public services and markets categorized by high scores in these use classes: medicinal, social, food additives, environmental, apicolous (of economic interest in apiculture), and toxic to nonvertebrates; and 2) Amazonian remote communities with high scores for these use classes: food, fuel, materials, vertebrate and invertebrate food, and toxic to vertebrates. Our findings suggest that economic and social development affects plant use patterns in a selective way. Some traditional uses will persist despite increased infrastructure development and habitat disturbance, whereas others that reflect subsistence strategies dependent on conserved natural habitats may soon disappear. The study incorporates more than 20 years of ethnobotanical research effort and a combined herbarium specimen database with more than 250,000 georeferenced records. As such, it provides a first example of how a biodiversity informatics approach can be used to take ethnobotanical analysis to new and larger scales.
\end{abstract}

Key Words: ecosystem diversity; human-plant interaction; plant species richness; socioeconomic, environmental, and geographical factors

\section{INTRODUCTION}

It is intuitively plausible that human communities that inhabit ecosystems rich in species also use a high number of species, and several studies have demonstrated just such a relationship (e.g., Begossi 1996, Salick et al. 1999, Begossi et al. 2002, Ladio and Lozada 2003, Ladio and Lozada 2004, Medley and Kalibo 2007, Thomas et al. 2008, de la Torre et al. 2009). Other studies have emphasized social, cultural, socioeconomic, and geographical factors as the main controllers of the number of species used by human communities (Ladio and Lozada 2001, Vandebroek et al. 2004, Byg et al. 2007).

Among nonbiotic factors that influence how local people use wild plants, market access appears to be one of the most important ones (Sierra et al. 1999a, Lawrence et al. 2005, Gray et al. 2008). Increasing market integration may lead to resource degradation or to the replacement of forest-based activities by nontraditional activities, some of which, such as cattle raising, result in forest clearing that, in turn, leads to a reduction in the number of wild species that are accessible to the communities affected (Sierra et al. 1999a, Godoy et al. 2005). The degree of market integration depends on factors such as the availability of, and distance to, markets and roads (Pan and
Bilsborrow 2005, Byg et al. 2007). Access to government services and infrastructure such as schools, health, electricity, or telephones may also affect the degree of reliance on plant resources, as well as the way they are used, which will translate into the use of fewer species from the surrounding ecosystem (Benz et al. 2000, Gray et al. 2008). For example, it has been shown that education, or homogenizing mass-media products such as radio and television, can increase acculturation and loss of traditional practices in plant use (Benz et al. 2000, Sternberg et al. 2001, Pan and Bilsborrow 2005). Finally, variables such as population density, urbanization, migration, and labor mobility may reduce the number of species extracted for use from the surrounding vegetation (Browder 2002, Rudel et al. 2002, Gray et al. 2008). For instance, higher population density and progressing urbanization often translates into higher environmental impacts and less availability of natural habitats (Pautasso 2007, Gray et al. 2008). Therefore, integration into global market economies and subsequent decreased reliance on forest resources may have a stronger impact on the number of plants and the way they are used than ethnicity or historical factors such as the period of time that a community has occupied a certain area (Lawrence et al. 2005, de la Torre et al. 2009).

\footnotetext{
${ }^{1}$ Herbario QCA, Pontificia Universidad Católica del Ecuador, ${ }^{2}$ Herbario Alfredo Paredes (QAP), Universidad Central del Ecuador, ${ }^{3}$ Department of Bioscience, Aarhus University
} 
Here, we test the relative importance of ecosystem species richness, and socioeconomic, environmental, and geographical factors, in determining the number of plant species used by people, along with the relative importance of different use categories. To do so, we compare data from a series of ethnobotanical inventories from Ecuador with data on ecosystem species richness derived from very large botanical databases. Ecuador provides an ideal case for testing general hypotheses regarding the relationship between people's plant use, and ecological and cultural diversity. It is a megadiverse country with 46 vegetation types (Sierra et al. 1999b) and more than 17,000 vascular plant species (Ulloa Ulloa and Neill 2005, Jørgensen et al. 2006). Moreover, the country is inhabited by 17 different cultural groups, including indigenous people and "mestizos," that is, those of mixed racial origin, who have interacted with a variety of ecosystems that differ highly in their species richness. Most groups live in rural communities that actively interact with the biological diversity of the surrounding ecosystem, as demonstrated by the fact that one third of all Ecuadorian plant species are being used by people (de la Torre et al. 2008).

Ethnobotanical research has a long tradition in Ecuador (de la Torre and Macía 2008), dating back to the 18th century (de Velasco 1978, Estrella 1991). The last three decades in particular have seen a multiplicity of ethnobotanical studies, some focusing on specific use categories (e.g., Estrella 1988, Acosta-Solís 1992) or ethnic groups (see references in Table 1). In the same period, the methodological approach has changed considerably, from descriptive-narrative to quantitative-synthetic, allowing a better understanding of the patterns of plant use, and also producing much more complete ethnobotanical inventories (e.g., Paz y Miño et al. 1991, Cerón and Montalvo 1998, Báez 1999, Macía et al. 2001, Macía 2004, Cerón et al. 2005a, b).

Within the framework described above, we were specifically interested in understanding 1) whether the number of plant species used by rural communities is related to the diversity of plants in the surrounding ecosystem, 2) whether there is a parallel influence of socioeconomic, environmental, and geographical factors on the number of species used, and 3) how the pattern of plant use, i.e., the relative frequency of different use categories such as food, medicine, materials, etc., changes in relation to these factors.

\section{METHODS}

\section{Ethnobotanical Information}

Data concerning numbers of species used, along with use categories, was compiled for 40 communities across Ecuador (Fig. 1) based on published and unpublished studies (Table 1). These 40 communities were selected from a pool of more than 100 sites in Ecuador where ethnobotanical studies have been conducted, and are those with the most complete data.
Of the 40 communities selected, 33 were studied by the Ecuadorian ethnobotanist Carlos Cerón using a uniform methodology. Data were compiled from publications and one unpublished thesis, and supplemented by additional information from Cerón's field books and herbarium vouchers collected in connection with the studies (Table 1). All data were entered in a database on Ecuadorian plant uses (de la Torre et al. 2008).

To control for sampling effort, the 40 communities were divided into two categories, according to the duration of field work and the techniques employed. Category 1 communities $(n=19)$ represented an intermediate study effort. All of these were studied by Cerón during 5-15 days of fieldwork, and included a number of $0.1-0.5$ ha transects established to collect herbarium specimens and record plant names and uses from local informants. Category 2 communities $(n=21)$ represented the highest study effort, and we estimate that these inventories are nearly complete, regardless of some variation in the methodology applied. Fourteen Category 2 communities were studied by Cerón, during 30-100 days of fieldwork in each community. Data collection involved semistructured interviews, and the establishment of transects $(0.1-0.5 \mathrm{ha})$, permanent plots ( $1 \mathrm{ha}$ ), and paths (usually $2 \mathrm{~km}$ long) in representative vegetation types surrounding the community, in areas where all plants being used had been identified by local informants. A more detailed description of Cerón's methods is given in Appendix 1. The remaining seven Category 2 communities (Table 1 ) have been the subject of very intensive studies published by other authors. For each community, from the ethnobotanical data we extracted the number of plant species used. In addition, we assigned each use reported to one of 12 use categories (Cook 1995, as modified by de la Torre et al. 2008). These categories are: 1) food, 2) food additives, 3) vertebrate food, 4) invertebrate food, 5) apicolous (of economic interest in apiculture), 6) fuel, 7) materials, 8) social, 9) toxic to vertebrates, 10) toxic to nonvertebrates, 11) medicinal, and 12) environmental. A detailed definition of these categories is provided in Appendix 2.

\section{Ecosystem Plant Species Richness}

To estimate the species richness of the ecosystem surrounding each community, we first compiled a database with 262,295 georeferenced herbarium specimen records from Ecuador, combining data from the herbarium databases of the Missouri Botanical Garden (MO), including collections from the Natio nal Herbarium of Ecuador (QCNE), Aarhus University (AAU) Pontificia Universidad Católica del Ecuador (QCA), and Universidad Central del Ecuador (QAP). Note that herbarium acronyms have been provided following the Index Herbarior um of the New York Botanical Garden. We then determined all vegetation types present within $10 \mathrm{~km}$ of the communities where the 40 ethnobotanical studies had been made. For this, we used Sierra et al.'s (1999b) vegetation map, which 
Table 1. Ecuadorian localities selected for the assessment of determinants of their plant use richness and use patterns.

\begin{tabular}{|c|c|c|c|c|c|}
\hline No. & Locality & $\begin{array}{l}\text { Study } \\
\text { category } \dagger\end{array}$ & Region & Ethnic group & Source \\
\hline 1 & Dureno & 2 & Amazon & Cofan & Cerón 1995, C. E. Cerón (personal observation \\
\hline 2 & Sinangue & 2 & Amazon & Cofan & Cerón et al. 1994a, C. E. Cerón (personal observation) \\
\hline 3 & Jatuncocha & 2 & Amazon & Kichwa of the Amazon & Cerón 2003, C. E. Cerón (personal observation) \\
\hline 4 & Limoncocha & 2 & Amazon & Kichwa of the Amazon & Cerón et al. 2005c, C. E. Cerón (personal observation) \\
\hline 5 & Oglan & 2 & Amazon & Kichwa of the Amazon & C. E. Cerón (personal observation) \\
\hline 6 & Copal & 2 & Amazon & Secoya & $\begin{array}{l}\text { Cerón et al. } 2005 a, b, \text { C. E. Cerón (personal } \\
\text { observation) }\end{array}$ \\
\hline 7 & San Pablo & 2 & Amazon & Secoya & $\begin{array}{l}\text { Cerón et al. } 2005 a, b, \text { C. E. Cerón (personal } \\
\text { observation) }\end{array}$ \\
\hline 8 & Dicaro & 2 & Amazon & Wao & Macía et al. 2001 \\
\hline 9 & Quehueiri-ono & 2 & Amazon & Wao & $\begin{array}{l}\text { Cerón and Montalvo 1998, C. E. Cerón (personal } \\
\text { observation) }\end{array}$ \\
\hline 10 & Tiputini & 2 & Amazon & Wao & Macía et al. 2001 \\
\hline 11 & Yasuni & 2 & Amazon & Wao & $\begin{array}{l}\text { Cerón and Montalvo 2002a, C. E. Cerón (personal } \\
\text { observation) }\end{array}$ \\
\hline 12 & Alao & 2 & Andes & Kichwa of the Andes & $\begin{array}{l}\text { Cerón and Montalvo 2002b, C. E. Cerón (personal } \\
\text { observation) }\end{array}$ \\
\hline 13 & Quilotoa & 2 & Andes & Kichwa of the Andes & Cerón et al. 1994b, C. E. Cerón (personal observation) \\
\hline 14 & Saraguro & 2 & Andes & Kichwa of the Andes & Ellemann 1990 \\
\hline 15 & Pululahua & 2 & Andes & Mestizo & Cerón 1993a, C. E. Cerón (personal observation) \\
\hline 16 & Manglares Churute & 2 & Coast & Mestizo & C. E. Cerón (personal observation) \\
\hline 17 & Puna & 2 & Coast & Mestizo & Madsen et al. 2001 \\
\hline 18 & San Marcos & 2 & Coast & Awa & $\begin{array}{l}\text { Barfod and Kvist 1996, A. Barfod and L. P. Kvist } \\
\text { (personal communication) }\end{array}$ \\
\hline 19 & Zapallo Grande & 2 & Coast & Chachi & $\begin{array}{l}\text { Barfod and Kvist 1996, A. Barfod and L. P. Kvist } \\
\text { (personal communication) }\end{array}$ \\
\hline 20 & Chiguilpe & 2 & Coast & Tsa'chi & Cerón et al. 2004, C. E. Cerón (personal observation) \\
\hline 21 & Congoma Grande & 2 & Coast & Tsa'chi & $\begin{array}{l}\text { Barfod and Kvist 1996, A. Barfod and L. P. Kvist } \\
\text { (personal communication) }\end{array}$ \\
\hline 22 & Cuyabeno & 1 & Amazon & Cofan & Cerón et al. 2006, C. E. Cerón (personal observation) \\
\hline 23 & Guagua Sumaco & 1 & Amazon & Kichwa of the Amazon & Cerón 1993b, C. E. Cerón (personal observation) \\
\hline 24 & Huiruno & 1 & Amazon & Kichwa of the Amazon & Cerón 1993b, C. E. Cerón (personal observation) \\
\hline 25 & Jatun Sacha & 1 & Amazon & Kichwa of the Amazon & C. E. Cerón (personal observation) \\
\hline 26 & Sehuaya & 1 & Amazon & Secoya & $\begin{array}{l}\text { Cerón et al. } 2005 a, b, \text { C. E. Cerón (personal } \\
\text { observation) }\end{array}$ \\
\hline 27 & Ambuqui & 1 & Andes & Mestizo & $\begin{array}{l}\text { Cerón and Montesdeoca 1994, C. E. Cerón (personal } \\
\text { observation) }\end{array}$ \\
\hline 28 & Upano & 1 & Andes & Mestizo & Cerón 2002a, C. E. Cerón (personal observation) \\
\hline 29 & Guayllabamba & 1 & Andes & Mestizo & $\begin{array}{l}\text { Cerón and Montesdeoca 1994, C. E. Cerón (personal } \\
\text { observation) }\end{array}$ \\
\hline 30 & Loma San José & 1 & Andes & Mestizo & C. E. Cerón (personal observation) \\
\hline 31 & Pasochoa & 1 & Andes & Mestizo & C. E. Cerón (personal observation) \\
\hline 32 & Pondoa & 1 & Andes & Mestizo & Cerón 2002b, C. E. Cerón (personal observation) \\
\hline 33 & Salinas & 1 & Andes & Mestizo & $\begin{array}{l}\text { Cerón and Montesdeoca 1994, C. E. Cerón (personal } \\
\text { observation) }\end{array}$ \\
\hline 34 & San Gabriel & 1 & Andes & Mestizo & $\begin{array}{l}\text { Cerón and Pozo 1994, C. E. Cerón (personal } \\
\text { observation) }\end{array}$ \\
\hline 35 & Chiriboga & 1 & Andes & Mestizo & C. E. Cerón (personal observation) \\
\hline 36 & Agua Blanca & 1 & Coast & Mestizo & Cerón 1993c, C. E. Cerón (personal observation) \\
\hline 37 & Cerro Blanco & 1 & Coast & Mestizo & Cerón 2002c, C. E. Cerón (personal observation) \\
\hline 38 & San Sebastian & 1 & Coast & Mestizo & Cerón 1993c, C. E. Cerón (personal observation) \\
\hline 39 & Playa de Oro & 1 & Coast & Afroecuadorian & Cerón 2001, C. E. Cerón (personal observation) \\
\hline 40 & Guadualito & 1 & Coast & Awa & $\begin{array}{l}\text { Cerón and Montalvo 2002c, C. E. Cerón (personal } \\
\text { observation) }\end{array}$ \\
\hline
\end{tabular}

†"Study category" refers to the sampling effort intensity as described in the methods section.

¥"Personal observation" or "personal communication" indicates that published information was complemented by unpublished data compiled from field books and herbarium sheets. 
Fig. 1. Vegetation map of Ecuador (Sierra et al. 1999b) and location of the 40 study localities. $\dagger$

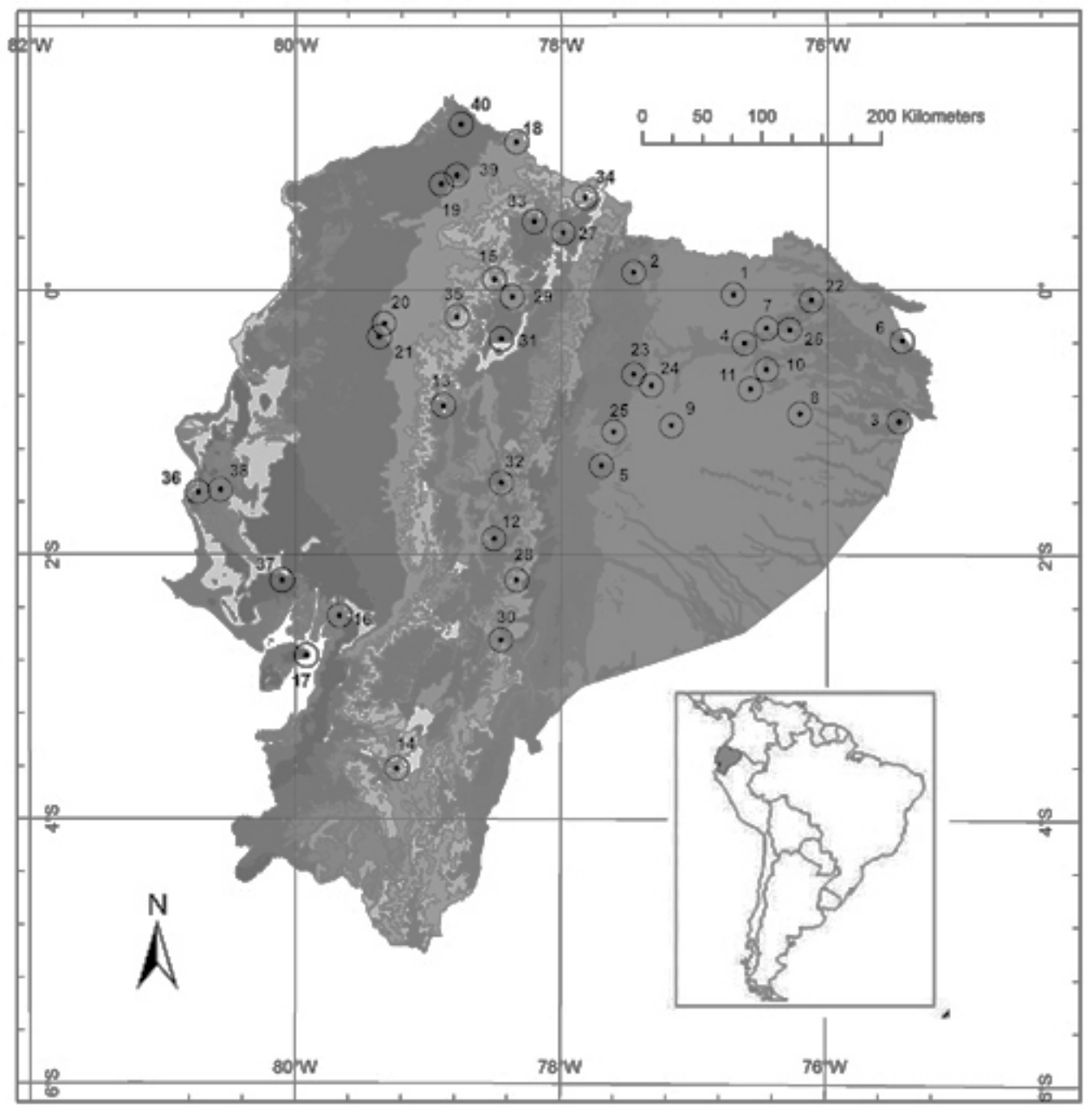

$\dagger$ Numbers refer to Table 1.

recognizes 46 major vegetation types in Ecuador mapped as polygons. A $10 \mathrm{~km}$ radius was chosen as an approximation of the range in which most human harvesting of natural plant resources occurs (Zapata et al. 2006, Pautasso 2007). Finally, we selected all herbarium specimens collected within the vegetation polygons touched by the $10 \mathrm{~km}$ radius circle and used these to determine ecosystem plant species richness. The vegetation-type approach was chosen instead of a method based on predefined grids or circles, to compensate for the scarcity of herbarium specimens at smaller scales, while at the same time avoiding inclusion of vegetation types beyond the reach of a community. Differences in plant collection intensity were compensated for by using rarefaction in EcoSim 7 software (Gotelli and Entsminger 2008). Species richness was determined from subsamples of 800 specimens, which was the maximum number of specimens available for all sample points. For a few Category 1 communities, the ethnobotanical effort was specifically directed toward a subset of the vegetation types surrounding the village. In this case, ecosystem species richness was estimated only on the basis of the polygons defined by the vegetation types covered by the study.

\section{Additional Explanatory Variables}

To estimate the effect of socioeconomic, environmental and geographical factors on the number of plant species used, we derived 13 indicator variables for each of the 40 studied communities (Table 2) from the most recent national population census (Instituto Nacional de Estadísticas y Censos 2002), the Integrated System of Social Indicators of Ecuador (Sistema Integrado de Indicadores Sociales del Ecuador 2005), and the Monitoring Socio-environmental System of Ecuador (Ecociencia 2002). A detailed description of these variables is provided in Appendix 3. Most variables were scored at the 
level of the "cantón," as this is the smallest political division in Ecuador for which such data exist. Geographical variables, including the distance to a main market, the distance to the province capital, and road access, were scored for each community using the Ecuador road network map (Dirección Nacional de Recursos Naturales Renovables del Ecuador 2002).

\section{Statistical Analysis}

Given strong co-linearity among the socioeconomic, environmental, and geographical indicator variables, we performed a principal components analysis (PCA; Legendre and Legendre 1998), maintaining only components with eigenvalues $>1.0$. These components were then used in a second step to model the number of plants used.

Table 2. Rotated principal components that reduced colinearity among 13 socioeconomic, environmental, and geographical indicator variables of 40 studied localities in Ecuador $\dagger$

\begin{tabular}{lccc}
\hline \hline Component & 1 & 2 & 3 \\
\hline Eigenvalue & 8.48 & 1.70 & 1.06 \\
Percentage of variance & 65.20 & 13.06 & 8.15 \\
Cumulative percentage of & 65.20 & 78.25 & 86.40 \\
variance & & & \\
Loadings of variables & & & \\
Electricity access & $0.61 \dagger$ & $-0.61 \dagger$ & -0.27 \\
Telephone access & $0.86 \dagger$ & -0.15 & -0.42 \\
Tap water access & $0.76 \dagger$ & -0.27 & -0.36 \\
Health index & $0.93 \dagger$ & -0.15 & -0.22 \\
Uncovered basic needs index & $-0.89 \dagger$ & 0.30 & 0.25 \\
Education index & $0.93 \dagger$ & -0.19 & -0.28 \\
Urban population & 0.83 & -0.33 & -0.20 \\
Population density & $0.91 \dagger$ & -0.06 & -0.18 \\
Vegetation remnancy index & -0.25 & $0.93 \dagger$ & 0.21 \\
Vegetation fragmentation & -0.13 & $0.94 \dagger$ & 0.23 \\
index & & & \\
Market distance & -0.26 & 0.27 & $0.79 \dagger$ \\
Province capital distance & -0.23 & 0.12 & $0.86 \dagger$ \\
Road access & 0.35 & -0.27 & $-0.70 \dagger$ \\
\hline
\end{tabular}

$\dagger$ Represents the highest loadings of each ordination axis.

The number of plant species used was regressed against ecosystem plant species richness and the three principal components using standard OLS multiple regression. Prior to statistical analysis, the variable "number of plant species used" was $\log$ transformed to secure a normal distribution of residuals. We analyzed Category 1 and Category 2 communities together, including study type as a categorical variable to control for the general difference in level of study intensity. As results from Category 1 communities are assumed to be more prone to error caused by sampling artifacts, we also analyzed Category 2 communities separately.

A principal component analysis (PCA) ordination of 38 studied communities was conducted to explore use patterns, i.e., the distribution of use records on use categories, and the relationship between ordination axes and predictor variables. Information about use patterns was lacking for two communities (Dicaro and Tiputini) and, thus, they were excluded from this analysis. Data on use records were arcsinh transformed to obtain a normal distribution, as recommended by Fowler et al. (1998) for count data with zeros. The relationship between the ordination axes and the descriptor variables was analyzed using Spearman's rank correlation. All statistical analyses were carried out in JMP 7 software (SAS Institute).

\section{RESULTS}

The number of plant species used by the communities varied from 32 in San Gabriel, an Andean mestizo locality at 3000 m elevation, to 636 in Quehueiri-ono, a lowland Amazon indigenous locality. Principal component analysis of 13 socioeconomic, environmental, and geographical indicator variables resulted in three components with an eigenvalue $>1.0$ (Table 2). The first component, expressing "infrastructure development and population density," correlated positively with the electricity access, telephone access, tap water access, health index, education index, urban population, and population density variables, and negatively with the uncovered basic needs index. The second component, expressing "natural habitat conservation," correlated positively with vegetation remnancy and fragmentation indices. The third component, expressing "remoteness of the community," correlated positively with market and province capital distances, and negatively with road access.

A multiple regression model (Table 3 ) showed that ecosystem plant richness had a highly significant positive effect on the number of plant species used, both when all 40 communities were analyzed (Category 1 and 2) and when only intensively studied communities (Category 2) were analyzed. The study type, i.e., Category 1 or 2, also had a significant effect in the analysis of all 40 communities, whereas the three principal components extracted from socioeconomic, environmental, and geographical indicator variables had no significant effect in either analysis.

Ordination analysis (Fig. 2) grouped communities into two clusters along the first and second ordination axes. Together, these two axes explained $63.6 \%$ of the variance in the dataset. The first ordination axis gave a separation between communities with high study intensity (Category 2) and medium study intensity (Category 1 ). The second ordination axis separated a cluster of mostly Amazonian communities with high usage in these categories: "food," "fuel," "materials," "vertebrate," "invertebrate food," and "toxic to vertebrates" from one including mostly coastal lowlands and Andean communities with high frequencies in these categories: "medicinal," "social," "food additives," "environmental," "apicolous," and "toxic to nonvertebrates". 
Fig. 2. Biplot of the PCA ordination performed for the plant use patterns (distribution of use records on use categories) of 38 Ecuadorian localities. $\dagger$

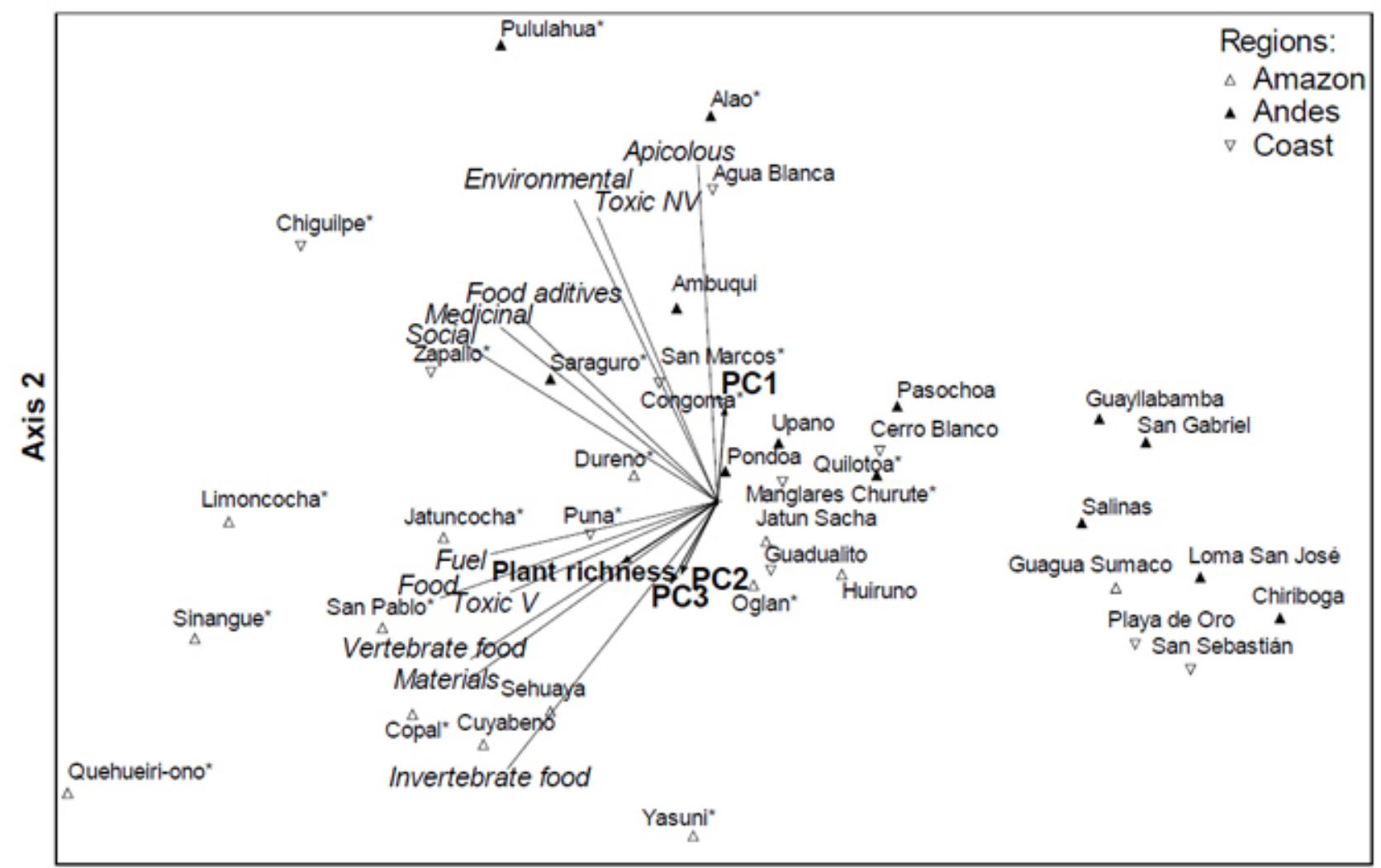

Axis 1

$\dagger$ Notes:

Axis 1: Eigenvalue $=5.7$; percent of variance explained $=47.6$.

Axis 2: Eigenvalue $=1.9$; percent of variance explained $=16.0$.

Bold arrows represent correlations between ordination axes and variables listed in Table 3.

Ordinary lines represent correlations between use categories of Cook (1995) as modified by de la Torre (2008) and ordination axes.

Toxic NV=Toxic to nonvertebrates.

Toxic V=Toxic to vertebrates.

Otherwise, full names of the use categories are given in the Figure.

A detailed explanation of use categories is given in Appendix 2.

Category 2 studies are marked by an asterisk $(*)$ after the community name. 
The first axis was significantly negatively correlated with ecosystem plant species richness $\left(\mathrm{r}_{\mathrm{s}}=-0.4 \mathrm{P}<0.05\right)$. The second axis was significantly positively correlated with PC1 reflecting infrastructure development and population density $\left(r_{s}=0.37 \mathrm{P}<0.05\right)$, and negatively with PC2 and PC3 reflecting natural habitat conservation $\left(r_{s}=-0.3 P<0.05\right)$ and remoteness of the community $\left(r_{s}=-0.5 \mathrm{P}<0.05\right)$.

Table 3. Effect of ecosystem plant species richness, socioeconomic, environmental, geographical, and methodological factors on plant use richness among 40 Ecuadorian localities.

\begin{tabular}{lcc}
\hline \hline Parameter & $\begin{array}{c}\text { All communities } \\
\mathrm{n}=40\end{array}$ & $\begin{array}{c}\text { Category 2 } \\
\text { communities } \\
\mathrm{n}=21\end{array}$ \\
\hline Model R-sq. & $0.67^{* *}$ & $0.43^{*}$ \\
Intercept & 0.12 & 0.74 \\
Ecosystem plant species richness & $0.0016^{*}$ & $0.0029^{*}$ \\
PC 1: Infrastructure development & -0.00027 & -0.012 \\
and population density & & \\
PC 2: Natural habitat conservation & 0.038 & -0.0063 \\
PC 3: Remoteness of the & 0.039 & 0.076 \\
community & & \\
Study category & $0.46^{* *}$ & $\mathrm{~N} / \mathrm{A}$ \\
\hline Significance levels: $* \mathrm{p}<0.05, * *<0.001$. & & \\
\end{tabular}

\section{DISCUSSION}

\section{Number of Plant Species Used}

The hypothesis that there is a positive relationship between the number of plant species used by a human community and the number of plant species present in the surrounding ecosystem is strongly supported by our results. To estimate ecosystem plant species richness, we used a large data set with close to 300,000 georeferenced herbarium collections. Museum data sets represent one of the best and largest sources of information on past and present biodiversity (Soberón and Peterson 2004), regardless of limitations resulting from potentially biased collecting efforts and the heterogeneity of sampling approaches (Lira-Noriega et al. 2007). We circumvented these limitations by using a very large botanical database, combined with rarefaction techniques, to estimate ecosystem plant richness in polygons of the vegetation types available for each locality.

The lack of standardized sampling techniques in ethnobotanical studies has previously hampered comparative studies (Reyes-García et al. 2007). Here, we use a large ethnobotanical dataset collected by a single researcher with a uniform technique supplemented with data from a few very intensively studied communities, which allowed us to extract the required information with a high degree of precision. In addition, we divided the studies into two categories according to sampling effort, and analyzed these both together and separately. This made it possible to demonstrate a statistically significant effect of ecosystem plant species richness in modeling the number of plant species used by a particular people, despite the added variance introduced by sampling artifacts.

We found no significant role for socioeconomic, environmental, and geographical indicators in explaining the number of plant species used by a community. However, such a role has been explicitly pointed to by other studies. Specific factors highlighted have included the remoteness of a community and its market access (Ladio and Lozada 2001, Byg et al. 2007); these have been cited as factors that explain the number of plant species used by a community irrespective of the levels of diversity of the surrounding ecosystem. This difference may have arisen because the cited studies focused only on currently practiced uses, rather than on all plant uses known to a community. Under changing livelihood conditions where new commodities or plant supplies become available through increased market access, modernization, and habitat destruction, the current uses of plants would be affected immediately, whereas all plant uses known to a community would remain constant until cumulative plant use knowledge changes over changing generations (Byg and Balslev 2001, Godoy et al. 2005, Reyes-García et al. 2005).

The ethnicity of the studied communities could potentially influence both the number of species used and their distribution among use categories, given different historical traditions (Atran et al. 1999, Ladio and Lozada 2001, Byg et al. 2007). Here, we were not able to address this question explicitly, given that the 21 Category 2 communities in our study represent eight different indigenous ethnic groups, so there would not be enough replication for statistical analysis. Only three of these intensively studied communities are "mestizo," i.e., represent a mixture between Spanish and (mostly) highland indigenous culture. The 19 Category 1 communities included in our analysis represent six different ethnicities, but the majority are mestizo $(n=12)$. Therefore, a general difference between indigenous and mestizo culture in our data would be confounded by the uneven representation of these two groups among the two categories of study types. The low representation of mestizo communities among the intensively studied communities provides a clear illustration of the general need to consider more than just indigenous communities in remote areas when planning ethnobotanical studies if general conclusions are to be achieved (Lawrence et al. 2005).

\section{Plant Use Patterns}

Unlike the number of species used, the distribution of uses among different categories showed a clear relationship to the three principal components extracted from socioeconomic, environmental, and geographical indicator variables. The use pattern also demonstrated a clear relationship to the number of species in the ecosystem where the communities are located. Thus, the main contrast found in our ordination analysis was 
one between well-connected Andean and coastal communities located in less diverse, more densely populated and disturbed environments, and isolated Amazonian communities with less access to services and markets, but surrounded by more species-rich, less populated, and better conserved ecosystems.

The use categories prevalent in Andean and coastal communities, that is, "medicinal," "social," "food additives," "environmental," "apicolous," and "toxic to nonvertebrates," possibly persist under increasing levels of infrastructural development because they address needs that are unaffected by changing livelihoods. One example is medicinal uses. A large part of the medicinal plants reported in Ecuador are herbaceous (de la Torre et al. 2008) and grow successfully in disturbed areas (Zimdahl 1999) and, therefore, remain available in disturbed habitats. Many societies in the Andean and coastal regions have a long contact history with western society, and exhibit higher population density and a sedentary way of life (Ayala 1995). All of these factors have been associated with higher levels of illness and, consequently, an increased demand for medicinal plants (Davis and Yost 1983a, Voeks 2004). Traditional medicine in the Andes and coastal lowlands is also maintained because it is used not only by rural residents but also by urban populations of all social classes, and a wide variety of medicinal plants are sold in markets in cities and towns across the country (Bussmann and Sharon 2006, Cerón 2006). Finally, cultural tradition may perhaps explain the persistence of some of these uses. For example, the Tsa'chi healers in the area around Santo Domingo de los Colorados in the coastal plain are considered the best "curanderos" in Ecuador, receiving patients from all over the country, and they even travel abroad to heal (Barfod and Kvist 1996, Cerón et al. 2004).

Other use categories prevalent in the Andes and the coastal lowlands can probably be explained in much the same way. "Food additives" in Ecuador are mainly herbs used as condiments; many of them are introduced, cultivated, and even commercialized (Van den Eynden and Cueva 2008). Therefore, the use of plants for this purpose thrives well in urban environments. The "toxic to nonvertebrates" use category includes plants that eliminate domestic insects that are highly important in precarious urban conditions with high population density, such as fleas, cockroaches, or mosquitoes, or to combat agricultural pests associated with marketoriented agriculture. Apiculture has been promoted by the Ecuadorian government as a source of income in rural areas of the dry coastal lowlands and Andes (Refinca 2008). Several apicolous plants are cultivated in Ecuador and the same species may be used for other commercial purposes such as for food, e.g. fruits of Coffea arabica, Citrus spp., Rubus niveus, Carica papaya, Persea americana, animal fodder (Medicago sativa) or wood (Eucalyptus spp.) (Carpio and Barragan 2008). The "environmental" use category includes mainly plants used in agroecosystems, i.e., for the establishment of living fences, fertilization through nitrogen fixation, and as ornamentals. Ornamental use has been related to increased market integration and lowered dependence on basic forests resources (de la Torre et al. 2009).

In contrast, the dominant use categories in Amazonian communities, that is, "food," "fuel," "materials," "vertebrate" and "invertebrate food," and "toxic to vertebrates," reflect a higher dependence on forest resources in areas with less access to modern services and commodities. Most of the material culture of the communities in the Amazon is based on forest resources. Plants are used for the construction and thatching of houses, for the manufacture of household utensils, agricultural tools, and articles for hunting and fishing. The less contact the group has had with the outside world, and the more remote it is, the greater is the association to these uses. For example, the Wao, the most recently contacted group, were traditionally seminomadic people that roamed large interfluvial areas hunting and gathering forest products while maintaining itinerant gardens (Davis and Yost 1983b). They stand out for the diversity of wild edible plants they use, mainly fruits, seeds, and palm hearts (Davis and Yost 1983b, Macía et al. 2001, Macía 2004). Like other Amazonian groups, they have an intimate knowledge of their prey animals (de la Torre et al. 2008), which is reflected in our data by a high frequency score for the "vertebrate food" category. The Wao are also recognized for the quality of their "curare" dart poison (Trupp 1981), which is so well known that other indigenous groups prefer to use it rather than using their own (Cerón and Montalvo 1998).

\section{CONCLUSION}

We have shown that the number of plant species used by a community is strongly associated with the number of species found in the ecosystem that surrounds it, whereas socioeconomic, environmental, and geographical factors, such as increased levels of market integration, education, access to public services, and habitat disturbance influence the ways in which plants are used in the communities. Together, these two findings provide a strong argument for the conservation of natural plant resources by stressing the general use value of plant diversity. At the same time, our work suggests that this value may be preserved as a society develops and changes its use patterns. Our study brings together decades of botanical and ethnobotanical investigation in Ecuador using a biodiversity informatics approach. Despite limitations intrinsic to museum collection data, we were able to reveal patterns at a country level from many individual and localized previous studies. Biodiversity informatics represents a new way of practicing ethnobotany, with great potential to contribute to a better understanding of questions that have already been asked, while also fostering the ability to address exciting new questions. 
Responses to this article can be read online at: http://www.ecologyandsociety.org/vol17/iss 1/art15/ responses/

\section{Acknowledgments:}

Studies were financed by the Ministry of Foreign Affairs of Denmark (DANIDA grants \# 104.Dan.8.L. 206 to HB and 104. Dan.8-896 to LdlT). Rodrigo Sierra kindly supplied us with access to a digital version of the vegetation map of Ecuador and made valuable comments on the manuscript. Jens Clausen allowed us to use his proof-read version of the Tropicos Ecuador plant specimen data. Jens-Christian Svenning and Stine Bjorholm provided methodological support and conceptual advice for this study. Carmita Reyes supported field data collection and digitalization at QAP.

\section{LITERATURE CITED}

Acosta-Solís, M. 1992. Vademécum de plantas medicinales del Ecuador. FESO, Abya-Yala, Quito, Ecuador.

Atran, S., D. Medin, N. Ross, E. Lynch, J. Coley, E. Ucan Ek, and V. Vapnarsky. 1999. Folkecology and commons management in the Maya Lowlands. Proceedings of the National Academy of Sciences of the United States of America 96:7598-7603. http://dx.doi.org/10.1073/pnas.96.13.7598

Ayala, M., editor. 1995. Nueva historia del Ecuador. Corporación Editora Nacional Grijalbo, Quito, Ecuador.

Báez, S. 1999. Uso de los recursos del bosque. Pages 55-67 in H. Borgtoft, F. Skov, J. Fjeldsaa, I. Schjellerup, and B. Øllgaard, editors. 1999. La gente y la biodiversidad, dos estudios en comunidades de las estribaciones de los Andes en Ecuador. Centro para la Investigación de la Biodiversidad Cultural y Biológica de los Bosques Pluviales Andinos (DIVA), Dinamarca; Abya-Yala, Quito, Ecuador.

Barfod, A. S., and L. P. Kvist. 1996. Comparative ethnobotanical studies of the Amerindian groups in coastal Ecuador. Biological Papers 46. The Royal Danish Academy of Science and Letters, Copenhagen, Denmark.

Begossi, A. 1996. Use of ecological methods in ethnobotany: diversity indices. Economic Botany 50:280-289. http://dx.doi. org/10.1007/BF02907333

Begossi, A., N. Hanazaki, and J. Y. Tamashiro. 2002. Medicinal plants in the Atlantic forest (Brazil): knowledge, use, and conservation. Human Ecology 30:281-299. http://dx. doi.org/10.1023/A:1016564217719

Benz, B. F., J. Cevallos, F. Santana, J. Rosales, and S. Graf. 2000. Losing knowledge about plant use in the Sierra de Manantlan Biosphere Reserve, Mexico. Economic Botany 54:183-191. http://dx.doi.org/10.1007/BF02907821
Browder, J. O. 2002. The urban-rural interface: urbanization and tropical forest cover change. Urban Ecosystems 6:21 -41. http://dx.doi.org/10.1023/A:1025962512653

Bussmann, R., and D. Sharon. 2006. Traditional medicinal plant use in Loja province, Southern Ecuador. Journal of Ethnobiology and Ethnomedicine 2:44. http://dx.doi.org/10.1 186/1746-4269-2-44

Byg, A., and H. Balslev. 2001. Traditional knowledge of Dypsis fibrosa (Arecaceae) in eastern Madagascar. Economic Botany 55:263-275. http://dx.doi.org/10.1007/BF02864564

Byg, A., J. Vormisto, and H. Balslev. 2007. Influence of biodiversity and road access on palm extraction at landscape scale in SE Ecuador. Biodiversity and Conservation 16:631642. http://dx.doi.org/10.1007/s10531-005-1342-y

Carpio, C., and A. Barragán. 2008. Plantas apícolas. Pages 80-82 in L. de la Torre, H. Navarrete, M. P. Muriel, M. J. Macía, and H. Balslev, editors. 2008. Enciclopedia de las plantas útiles del Ecuador. Herbario QCA de la Escuela de Ciencias Biológicas de la Pontificia Universidad Católica del Ecuador and Herbario, AAU Department of Biological Sciences, University of Aarhus, Quito, Ecuador and Aarhus, Denmark. http://puceqca.puce.edu.ec/fmi/iwp/cgi?-db=www\&loadframes.

Cerón, C. E. 1993a. Plantas útiles de la Reserva Geobotánica del Pululahua. Hombre y Ambiente 25:9-72.

Cerón, C. E. 1993b. Etnobotánica Quichua en la vía HollínLoreto, provincia del Napo. Hombre y Ambiente 25:131-171.

Cerón, C. E. 1993c. Estudio preliminar de plantas útiles del Parque Nacional Machalilla. Hombre y Ambiente 25:73-130.

Cerón, C. E. 1995. Etnobiología de los cofanes de Dureno, provincia de Sucumbíos, Ecuador. Museo Ecuatoriano de Ciencias Naturales, and Abya-Yala, Serie Pueblos del Ecuador 1, Quito, Ecuador.

Cerón, C. E. 2001. Caracterización botánica de la Comunidad Playa de Oro, cuenca del Río Santiago, provincia de Esmeraldas. Cinchonia 2:30-65.

Cerón, C. E. 2002a. Etnobotánica del Río Upano, sector Purshi-Zuñac, Parque Nacional Sangay. Cinchonia 3:36-45.

Cerón, C. E. 2002b. Etnobotánica del Pondoa, volcán Tungurahua. Cinchonia 3:26-35.

Cerón, C. E. 2002c. Aportes a la flora útil de Cerro Blanco, Guayas-Ecuador. Cinchonia 3:17-25.

Cerón, C. E. 2003. Etnobotánica Quichua del Río Yasuní, Amazonía ecuatoriana. Cinchonia 4:1-20.

Cerón, C. E. 2006. Plantas medicinales de los Andes ecuatorianos. Pages 285-293 in M. Moraes, B. Øllgaard, L. 
P. Kvist, F. Borchsenius, and H. Balslev, editors. Botánica económica de los Andes centrales. Universidad Mayor de San Andrés, Plural Editores, La Paz, Bolivia.

Cerón, C. E., and C. Montalvo. 1998. Etnobotánica de los Huaorani de Quehueiri-Ono, Napo-Ecuador. First edition. Abya-Yala, Quito, Ecuador.

Cerón, C. E., and C. Montalvo. 2002a. Etnobotánica Huaorani de Tivacuno-Tiputini, Parque Nacional Yasuní. Cinchonia 3:64-94.

Cerón, C. E., and C. Montalvo. 2002b. Etnobotánica de la comunidad Alao, zona de influencia del Parque Nacional Sangay. Cinchonia 3:59-63.

Cerón, C. E., and C. Montalvo. 2002c. Etnobotánica Awá de Guadualito, San Lorenzo, Esmeraldas. Cinchonia 3:46-54.

Cerón, C. E., and M. C. Montesdeoca. 1994. Diversidad, composición y usos florísticos en la hoya de GuayllabambaChota, provincias de Pichincha e Imbabura. Hombre $y$ Ambiente 31:85-135.

Cerón, C. E., and E. Pozo. 1994. El bosque Los Arrayanes, San Gabriel, Carchi, importancia botánica. Hombre y Ambiente 31:137-164.

Cerón, C. E., C. Montalvo, J. Umenda, and E. Umenda. $1994 a$. Etnobotánica y notas sobre la diversidad vegetal en la comunidad Cofán de Sinangüé, Sucumbíos, Ecuador. Editcar, Quito, Ecuador.

Cerón, C. E., A. M. Quevedo, M. Reina, M. C. Montesdeoca, and E. Pozo. 1994b. Etnobotánica del Quilotoa, Cotopaxi. Hombre y Ambiente 31:39-84.

Cerón, C. E., C. Montalvo, A. Calazacón, and G. Toasa. 2004. Etnobotánica Tsáchila, Pichincha-Ecuador. Cinchonia 5:109_ 194.

Cerón, C. E., A. Payaguaje, D. Payaguaje, H. Payaguaje, C. I. Reyes, and P. Yépez. 2005a. Etnobotánica Secoya. Pages 71-84 in P. Yépez, S. de la Torre, C. E. Cerón, and W. Palacios, editors. Al inicio del sendero: estudios etnobotánicos Secoya. Arboleda, Quito, Ecuador.

Cerón, C. E., A. Payaguaje, D. Payaguaje, H. Payaguaje, C. I. Reyes, and P. Yépez. 2005b. El sendero etnobotánico Secoya "Sehuayeja", río Shushufindi, Sucumbíos, Ecuador. Pages 8593 in P. Yépez, S. de la Torre, C. E. Cerón, and W. Palacios, editors. Al inicio del sendero: estudios etnobotánicos Secoya. Arboleda, Quito, Ecuador.

Cerón, C. E., C. Montalvo, C. I. Reyes, and D. Andi. 2005 c. Etnobotánica Quichua Limoncocha, Sucumbíos, Ecuador. Cinchonia 6:29-55.

Cerón, C. E., C. Reyes, L. Tonato, A. Grefa, and M. Mendua. 2006. Estructura, composición y etnobotánica del sendero "Ccottacco shaiqui," Cuyabeno-Ecuador. Cinchonia 7:82114.
Cook, F. E. M. 1995. Economic botany data collection standard. Royal Botanic Gardens, Kew, United Kingdom.

Davis, E. W., and J. A. Yost. 1983a. The ethnomedicine of the Waorani of Amazonian Ecuador. Journal of Ethnopharmacology 9:272-297.

Davis, E. W., and J. A. Yost. 1983b. The ethnobotany of the Waorani of eastern Ecuador. Botanical Museum Leaflets 3:159-217.

http://dx.doi.org/10.1016/0378-8741(83)90036-3

de la Torre, L., H. Navarrete, M. P. Muriel, M. J. Macía, and H. Balslev, editors. 2008. Enciclopedia de las plantas útiles del Ecuador. Herbario QCA de la Escuela de Ciencias Biológicas de la Pontificia Universidad Católica del Ecuador and Herbario, AAU Department of Biological Sciences, University of Aarhus, Quito, Ecuador and Aarhus, Denmark. http://puceqca.puce.edu.ec/fmi/iwp/cgi?-db=www-loadframes

de la Torre, L., and M. J. Macía. 2008. La etnobotánica del Ecuador. Pages 13-27 in L. de la Torre, H. Navarrete, M. P. Muriel, M. J. Macía, and H. Balslev, editors. 2008. Enciclopedia de las plantas útiles del Ecuador. Herbario QCA de la Escuela de Ciencias Biológicas de la Pontificia Universidad Católica del Ecuador and Herbario, AAU Department of Biological Sciences, University of Aarhus, Quito, Ecuador and Aarhus, Denmark. http://puceqca.puce.edu. ec/fmi/iwp/cgi?-db=ww\&-loadframes

de la Torre, L., L. M. Calvo-Irabién, C. Salazar, H. Balslev, and F. Borchsenius. 2009. Contrasting palm species and use diversity in the Yucatan Peninsula and the Ecuadorian Amazon. Biodiversity and Conservation 18:2837-2853. http: //dx.doi.org/10.1007/s10531-009-9610-x

de Velasco, J. 1978. Historia del reino de Quito en la América meridional. Historia Natural. Volume I. Book II. Casa de la Cultura Ecuatoriana, Quito, Ecuador.

Dirección Nacional de Recursos Naturales Renovables del Ecuador (DINAREN). 2002. Mapa de infraestructura vial del Ecuador. Quito, Ecuador.

Ecociencia. 2002. Sistema preliminar de monitoreo socio ambiental del Ecuador. CD. Quito, Ecuador.

Ellemann, L. 1990. Saraguroerne og deres planter-en gruppe højlandsindianeres anvendelse af den naturlige vegetation. Thesis. Aarhus University, Aarhus, Denmark.

Estrella, E. 1988. El pan de América: etnohistoria de los alimentos aborígenes en el Ecuador. Abya-Yala, Quito, Ecuador.

Estrella, E. 1991. Flora huayaquilensis: la expedición botánica de Juan Tafalla a la real audiencia de Quito 17991808. Abya-Yala, Quito, Ecuador. 
Fowler, J., L. Cohen, and P. Jarvis. 1998. Practical statistics for field biology. Second edition. Wiley, New York, New York, USA.

Godoy, R., V. Reyes-García, E. Byron, W. Leonard, and V. Vadez. 2005. The effect of market economies on the wellbeing of indigenous peoples and on their use of renewable natural resources. Annual Review of Anthropology 34:121138. http://dx.doi.org/10.1146/annurev.anthro.34.081804.120412

Gotelli, N. J., and G. L. Entsminger. 2008. EcoSim: null models software for ecology. Version 7. Acquired Intelligence Inc. and Kesey-Bear. Jericho, Vermont, USA.

Gray, C. L., R. E. Bilsborrow, J. L. Bremer, and F. Lu. 2008. Indigenous land use in the Ecuadorian Amazon: a crosscultural and multilevel analysis. Human Ecology 36:97-109. http://dx.doi.org/10.1007/s10745-007-9141-6

Instituto Nacional de Estadísticas y Censos (INEC). 2002. VI Censo de población y V de vivienda 2001: resultados definitivos. CD. Quito, Ecuador.

Jørgensen, P. M., C. Ulloa Ulloa, and C. Maldonado. 2006. Riqueza de plantas vasculares. Pages $37-50$ in M. Moraes, B. Øllgaard, L. P. Kvist, F. Borchsenius, and H. Balslev, editors. Botánica económica de los Andes centrales. Universidad Mayor de San Andrés, Plural Editores, La Paz, Bolivia.

Ladio, A. H., and M. Lozada. 2001. Nontimber forest product use in two human populations from northwest Patagonia: a quantitative approach. Human Ecology 29:367-380. http://dx. doi.org/10.1023/A:1013199103440

Ladio, A. H., and M. Lozada. 2003. Comparison of wild edible plant diversity and foraging strategies in two aboriginal communities of northwestern Patagonia. Biodiversity and Conservation 12:937-951. http://dx.doi.org/10.1023/A:10228 $\underline{73725432}$

Ladio, A. H., and M. Lozada. 2004. Patterns of use and knowledge of wild edible plants in distinct ecological environments: a case study of a Mapuche community from northwestern Patagonia. Biodiversity and Conservation 13:1153-73. http://dx.doi.org/10.1023/B:BIOC.0000018150. $\underline{79156.50}$

Lawrence, A., O. L. Phillips, A, Reategui Ismodes, M. Lopéz, S. Rose, D., Wood, and A. J. Farfan. 2005. Local values for harvested forest plants in Madre de Dios, Peru: towards a more contextualized interpretation of quantitative ethnobotanical data. Biodiversity and Conservation 14:45-79. http://dx.doi.o rg/10.1007/s10531-005-4050-8

Legendre, P., and L. Legendre. 1998. Numerical Ecology. Third edition. Elsevier, Amsterdam, Netherlands.

Lira-Noriega, A., J. Soberón, A. G. Navarro-Sigüenza, Y. Nakazawa, and A. T. Peterson. 2007. Scale dependency of diversity components estimated from primary biodiversity data and distribution maps. Diversity and Distributions 13:185-195. http://dx.doi.org/10.1111/j.1472-4642.2006.00304. $\underline{\mathrm{x}}$

Macía, M. J. 2004. Multiplicity in palm uses by the Huaorani of Amazonian Ecuador. Botanical Journal of the Linnean Society 144:149-159. http://dx.doi.org/10.1111/j.1095-8339. 2003.00248.x

Macía, M. J., H. Romero-Saltos, and R. Valencia. 2001. Patrones de uso en un bosque primario de la Amazonía ecuatoriana: comparación entre dos comunidades Huaorani. Pages 225-249 in J. F. Duivenvoorden, H. Balslev, J. Cavalier, C. Grandez, H. Tuomisto and R. Valencia, editors. Evaluación de recursos vegetales no maderables en la Amazonía noroccidental. Institute for Biodiversity and Ecosystem Dynamics, University of Amsterdam, Amsterdam, Netherlands.

Madsen, J. E., R. Mix, and H. Balslev. 2001. Flora of Puná Island. Aarhus University Press, Aarhus, Denmark.

Medley, K. E., and H. W. Kalibo. 2007. Global localism: recentering the research agenda for biodiversity conservation. Natural Resources Forum 31:151-161. http://dx.doi.org/10.1 111/j.1477-8947.2007.00137.x

Pan, W., and R. Bilsborrow. 2005. The use of a multilevel statistical model to analyze factors influencing land use: a study of the Ecuadorian Amazon. Global and Planetary Change 47:232-252. http://dx.doi.org/10.1016/j.gloplacha.20 $\underline{04.10 .014}$

Pautasso, M. 2007. Scale dependence of the correlation between human population presence and vertebrate and plant species richness. Ecology Letters 10:16-24. http://dx.doi.org/ 10.1111/j.1461-0248.2006.00993.x

Paz y Miño, G., H. Balslev, and R. Valencia. 1991. Aspectos etnobotánicos de las lianas utilizadas por los indígenas SionaSecoya de la Amazonía del Ecuador. Pages 105-118 in M. Ríos and H. Borgtoft Pedersen, editors. 1991. Las plantas y el hombre. Abya-Yala, Quito, Ecuador.

Refinca. 2008. Reconversión de pequenas fincas cafetaleras en unidades familiares agropecuarias autosostenibles. http:// issuu.com/telandweb/docs/refincaavanceene09/1 mode $=\mathrm{a} p$

Reyes-García, V., V. Vadez, T., Huanca, W. Leonard, and D. Wilkie. 2005. Knowledge and consumption of wild plants: a comparative study in two Tsimane' villages in the Bolivian Amazon. Ethnobotany Research and Applications 3:201207.

Reyes-García, V., N. Martí, T. Mcdade, S. Tanner, and V. Vadez. 2007. Concepts and methods in studies measuring individual etnbonotanical knowledge. Journal of Ethnobiology 27:182-203. http://dx.doi.org/10.2993/0278-0771(2007)27[182: CAMISM]2.0.CO;2 
Rudel, T. K., D. Bates, and R. Machinguiashi. 2002. A tropical forest transition? Agricultural change, out-migration, and secondary forests in the Ecuadorian Amazon. Annals of the Association of American Geographers 92:87-102. http://dx.d oi.org/10.1111/1467-8306.00281

Salick, J., A. Biun, G. Martin, L. Apin, and R. Beaman. 1999. Whence useful plants? A direct relationship between biodiversity and useful plants among Dusun of Mt. Kinabalu. Biodiversity and Conservation 8:797-818. http://dx.doi.org/1 0.1023/A:1008853413930

Sierra, R., F. Rodríguez, and E. Losos. 1999a. Forest resource use change during early market integration in tropical rain forests: the Huaorani of upper Amazonia. Ecological Economics 30:107-119.

Sierra, R., C. E. Cerón, W. Palacios, and R. Valencia. $1999 b$. Mapa de vegetación del Ecuador continental. Escala 1:1'000.000. Project INEFAN/GEF-BIRF, Wildlife Conservation Society and EcoCiencia, Quito, Ecuador. http://dx.doi.org/10 .1016/S0921-8009(98)00101-3

Sistema Integrado de Indicadores Sociales del Ecuador (SIISE). 2005. CD version 4.5. Quito, Ecuador.

Soberón, J., and A. T. Peterson. 2004. Biodiversity informatics: managing and applying primary biodiversity data. The Philosophical Transactions of the Royal Society 359:689-698. http://dx.doi.org/10.1098/rstb.2003.1439

Sternberg, R., C. Nokes, P. Geissler, R. Prince, F. Okatcha, D. Bundy, and E. Grigorenko. 2001. The relationship between academic and practical intelligence: a case study in Kenya. Intelligence 29:401-18. http://dx.doi.org/10.1016/S0160-2896 (01)00065-4

Thomas, E., I. Vandebroek, P. Van Damme, P. Goetghebeur, S. Sanca, and S. Arrazola. 2008. The relationship between plant use and plant diversity in the Bolivian Andes, with special reference to medicinal plant use. Human Ecology 36:861-879. http://dx.doi.org/10.1007/s10745-008-9208-z

Trupp, F. 1981. The last Indians: South America's cultural heritage. Perlinger, Austria.

Ulloa Ulloa, C., and D. Neill. 2005. Cinco años de adiciones a la flora del Ecuador 1999-2004. Editorial UTPL, Loja, Ecuador.

Vandebroek, I., P. Van Damme, L.Van Puyvelde, S. Arrazola, and N. De Kimpe. 2004. A comparison of traditional healers' medicinal plant knowledge in the Bolivian Andes and Amazon. Social Science and Medicine 59:837-849. http://dx. doi.org/10.1016/j.socscimed.2003.11.030

Van den Eynden, V., and V. E. Cueva. 2008. Uso de plantas como aditivos en la alimentación. Pages 67-70 in L. de la Torre, H. Navarrete, M. P. Muriel, M. J. Macía, and H. Balslev,
H., editors. 2008. Enciclopedia de las plantas útiles del Ecuador. Herbario QCA de la Escuela de Ciencias Biológicas de la Pontificia Universidad Católica del Ecuador and Herbario, AAU Department of Biological Sciences, University of Aarhus, Quito, Ecuador and Aarhus, Denmark. http://puceqca.puce.edu.ec/fmi/iwp/cgi?-db=www\&-loadframes

Voeks, R. A. 2004. Disturbance pharmacopoeias: medicine and myth from the humid tropics. Annals of the Association of American Geographers 94:868-888.

Zapata, G., E. Suárez, V. Utreras, and J. Vargas. 2006. Evaluación de amenazas antropogénicas en el Parque Nacional Yasuní y sus implicaciones para la conservación de mamíferos silvestres. Lyonia 10:31-41.

Zimdahl, R. C. 1999. Fundamentals of weed science. Second edition. Academic Press, San Diego, USA. 


\section{APPENDIX 1.}

\section{An overview of the ethnobotanical field studies conducted by Carlos Cerón in the period 1993-2005.}

\section{General methodology}

Key informants were designated by members of the community according to their ethnobotanical knowledge. The number of informants varied from 1-11. After identification of the informants the location of representative patches of the different vegetation types available to the community was decided in collaboration with community members.

For category 0 studies data were gathered through random plant collections done with local informants who were interviewed informally during visits to paths and areas close and around the communities. For category 1 and 2 studies a plot-based semi-structured interview procedure was applied. The research team consisting of Carlos Cerón and at least one assistant walked together with the key informant(s) through transects, plots or paths (see table 1 below). Useful plant species were identified by the informants. Each identification was followed up by a semi-structured interview regarding starting out with same two basic questions: 1) What is this plant for? 2) Which part of the plant is used for that purpose? Several uses could be recorded for the same plant. Additional information that was offered during the conversation initiated by the two basic questions (i.e. preparation, harvest data, history) was also recorded, but this part of interview did not follow a predefined scheme. In each case a herbarium voucher for the identification of the plant was collected and prepared during the conversation.

Table A1.1. Overview of studies and their characteristics

\begin{tabular}{llll}
\hline Study category & $\mathbf{0}$ & $\mathbf{1}$ & $\mathbf{2}$ \\
\hline Number of communities & 88 & 19 & 14 \\
Study regions & Andes (86), Amazon (2) & $\begin{array}{l}\text { Andes (9), Coast (5), } \\
\text { Amazon (5) }\end{array}$
\end{tabular}




\section{Ethnicity}

\section{Duration of field}

work

Methodology

Notes
Mestizo (76), Kichwa of the Andes (10), Kichwa of the Amazon (1), Shuar (1)

Usually one weekend

Random plant collections done with local informants who were interviewed informally during visits to paths and areas close and around the communities.

The studies were performed mainly during weekends and by Carlos Cerón's undergraduate students. Type 0 studies are not included in the analysis as we judge the information too incomplete for our purpose
Mestizo (12), Kichwa of the Amazon (3), Cofan (1), Secoya (1), Awa (1),

Afroecuadorian (1)

$5-15$ days

Data recorded in transects (0.1 - 0.5 ha)

Commonly, these studies were conducted to assess the plant diversity and composition of the locality. Ethnobotanic information was a secondary priority but still thoroughly documented.
Kichwa of the Amazon (3), Mestizo (2), Kichwa of the Andes (2), Wao (2), Cofan (2), Secoya (2), Tsa'chi (1)

$30-100$ days

Data recorded in transects $(0.1$ - $0.5 \mathrm{ha}$ ) and/or permanent plots (1 ha) and/or by walking along paths (usually $2 \mathrm{~km}$ long) in representative vegetation types surrounding the community

In these studies the gathering of ethnobotanical data was the main focus 


\section{APPENDIX 2.}

Description of the 12 use categories as defined by Cook (1995) and modified by de la Torre et al. (2008) and used in this study for classifying plant use records.

\begin{tabular}{|c|c|}
\hline Use category & Description \\
\hline Food & $\begin{array}{l}\text { Plants eaten by human beings. Include plants used to make } \\
\text { beverages }\end{array}$ \\
\hline Food additives & $\begin{array}{l}\text { Processing additives and other additive ingredients used in } \\
\text { food or beverages preparation }\end{array}$ \\
\hline Vertebrate food & $\begin{array}{l}\text { Forage and fodder for domestic or wild vertebrates that } \\
\text { serve as a source of food for human beings }\end{array}$ \\
\hline $\begin{array}{l}\text { Invertebrate } \\
\text { food }\end{array}$ & $\begin{array}{l}\text { Plants eaten by invertebrates that are useful to humans, such } \\
\text { as edible grubs }\end{array}$ \\
\hline Apicolous & $\begin{array}{l}\text { Plants that provide pollen, nectar or resins as sources for } \\
\text { honey or propoleum production. This category was } \\
\text { separated from invertebrate food due to its importance in } \\
\text { developing countries as Ecuador }\end{array}$ \\
\hline Fuel & $\begin{array}{l}\text { Plants used to produce charcoal, or used as petroleum } \\
\text { substitutes, alcohols, or tinder }\end{array}$ \\
\hline Materials & $\begin{array}{l}\text { Plants used as source of materials for construction of } \\
\text { houses, fences or bridges, or to elaborate handicrafts, music } \\
\text { instruments, work tools, weapons, home objects, etc. This } \\
\text { category includes fibers, waxes, oils, chemicals and their } \\
\text { derived products }\end{array}$ \\
\hline Social & $\begin{array}{l}\text { Plants used for cultural purposes, which are not definable as } \\
\text { food or medicines. This category includes hallucinogens, } \\
\text { contraceptives and plants with ritual or religious } \\
\text { significance. Plants used to cure cultural disorders as "bad } \\
\text { air" are also included }\end{array}$ \\
\hline $\begin{array}{l}\text { Toxic to } \\
\text { vertebrates }\end{array}$ & $\begin{array}{l}\text { Plants that are poisonous to vertebrate animals, both } \\
\text { accidentally and when deliberately applied, such as extracts } \\
\text { and preparations used for fishing and hunting }\end{array}$ \\
\hline $\begin{array}{l}\text { Toxic to non } \\
\text { vertebrates }\end{array}$ & $\begin{array}{l}\text { Plants that are poisonous to non vertebrates, both } \\
\text { accidentally and when deliberately applied. This category } \\
\text { includes insecticides and herbicides }\end{array}$ \\
\hline Medicinal & Plants used to cure human and animal sicknesses \\
\hline Environmental & $\begin{array}{l}\text { Plants used to protect, improve, and fertilize soils; to } \\
\text { provide shadow, as living fences, ornamentals or that form a } \\
\text { structural part of agroforestry systems }\end{array}$ \\
\hline
\end{tabular}




\section{APPENDIX 3.}

Description of the 13 socioeconomic, environmental, and geographical variables of 40 studied localities in Ecuador.

\begin{tabular}{|c|c|c|c|}
\hline Name & Description & Level & Source \\
\hline \multicolumn{4}{|l|}{ Socioeconomic } \\
\hline 1. Electricity access & Percentage of households in cantón with electric service & Cantón & INEC 2002 \\
\hline 2. Telephone access & Percentage of households in cantón with telephone & Cantón & INEC 2002 \\
\hline 3. Tap water access & Percentage of households in cantón with access to a public net of tap water & Cantón & INEC 2002 \\
\hline 4. Health index & $\begin{array}{l}\text { A composite indicator combining information about health infrastructure, } \\
\text { availability of potable water, quality of sewer system, level of malnutrition } \\
\text { and population mortality }\end{array}$ & Cantón & SIISE 2005 \\
\hline $\begin{array}{l}\text { 5. Uncovered basic } \\
\text { needs index }\end{array}$ & $\begin{array}{l}\text { A composite indicator expressing the lack of access to education, good } \\
\text { nutrition, housing, electricity, tap water, and sewage system plus } \\
\text { employment opportunities and degree of overcrowding }\end{array}$ & Cantón & SIISE 2005 \\
\hline 6. Education index & $\begin{array}{l}\text { A composite indicator combining information about alphabetization rates, } \\
\text { access to schools and average years of school attendance }\end{array}$ & Cantón & SIISE 2005 \\
\hline 7. Urban population & Percentage of people living in urban centers & Cantón & INEC 2002 \\
\hline 8. Population density & Number of people per $\mathrm{km}^{2}$ & Cantón & INEC 2002 \\
\hline \multicolumn{4}{|l|}{ Environmental } \\
\hline $\begin{array}{l}\text { 9. Vegetation } \\
\text { remnancy index }\end{array}$ & $\begin{array}{l}\text { Area of remnant natural vegetation in the cantón divided by the total area of } \\
\text { the cantón. }\end{array}$ & Cantón & Ecociencia 2002 \\
\hline $\begin{array}{l}\text { 10. Vegetation } \\
\text { fragmentation index }\end{array}$ & $\begin{array}{l}\text { The ratio between the total area of remnant natural vegetation polygons (in } \\
\mathrm{km}^{2} \text { ) in the cantón and their perimeter in }(\mathrm{km}) \text {. }\end{array}$ & Cantón & Ecociencia 2002 \\
\hline
\end{tabular}




\begin{tabular}{|c|c|c|c|}
\hline Geographical & & & \\
\hline 11. Market distance & $\begin{array}{l}\text { Straight line distance (log transformed) from the community to the main } \\
\text { market available when the ethnobotanical study was carried out. The variable } \\
\text { is an indicator of the market opportunities of the localities population, } \\
\text { considering both the relative cost of bringing products to markets and the } \\
\text { level of stimulus that a market provides to change production and consume } \\
\text { patterns }\end{array}$ & Community & $\begin{array}{l}\text { DINAREN } \\
2002\end{array}$ \\
\hline $\begin{array}{l}\text { 12. Province capital } \\
\text { distance }\end{array}$ & $\begin{array}{l}\text { Straight line distance (log transformed) from the community to the province } \\
\text { capital. Represents the degree of isolation of the locality with respect to } \\
\text { governmental institutions (often located in the province capital) as well as } \\
\text { distance to big commercial markets. }\end{array}$ & Community & $\begin{array}{l}\text { DINAREN } \\
2002\end{array}$ \\
\hline 13. Road access & $\begin{array}{l}\text { Number and quality of roads available for each community in a radius of } 10 \\
\mathrm{~km} \text {. In weighting road quality a two-lane asphalted road was given a value of } \\
4 \text {; an one-lane asphalted road was given a value of } 3 \text {; a two lane dirt road } \\
\text { was given a value of } 2 \text {; and a one-lane dirt road was given a value of } 1 \text {. The } \\
\text { final value of road access was found by summing up values across all roads } \\
\text { available to the community. }\end{array}$ & Community & DINAREN 2002 \\
\hline
\end{tabular}

